\title{
A Study of Metal Chelation of Dinucleotide Analogs in the Gas Phase by Fast-Atom Bombardment Mass Spectrometry
}

\author{
Mandapati Saraswathi and Jack M. Miller \\ Department of Chemistry, Brock University, St. Catharines, Ontario L2S 3A1, Canada
}

\begin{abstract}
Fast-atom bombardment $(\mathrm{FAB})$ mass spectrometry was used to investigate the interaction of proton and alkali metal ions with dinucleotide analogs such as $\mathrm{T}-\mathrm{n}-\mathrm{T}(\mathrm{T}=$ thymine moiety, $\mathrm{n}=$ polyether chain, e.g., triethylene, tetraethylene, pentaethylene, and hexaethylene ether 1-4), A-n-T ( $A$ = adenine unit 5-8), and T-n-OMe (9-12) in 3-nitrobenzyl alcohol matrix. The $[\mathrm{M}+\mathrm{H}]^{+}$ion is the most abundant ion for the A-n-T series, whereas in 1-4 and 9-12 the $\left(\mathrm{TC}_{2} \mathrm{H}_{4}\right)^{+}$ion is the most abundant. Formation of $\left[\mathrm{M}+\mathrm{H}-\mathrm{C}_{2} \mathrm{H}_{4} \mathrm{O}\right]^{+}$ions, a characteristic fragmentation of crown ethers under electron ionization, is observed for compounds 1-12 and is more pronounced in 6 and 7. An abundant $[\mathrm{M}-\mathrm{H}]^{-}$ion is observed for all the compounds studied under negative ion FAB due to the presence of the $(-\mathrm{CO}-\mathrm{NH}-\mathrm{CO}-$ ) group of thymine, an indication of existence of intramolecular $\mathrm{H}$ bonding. The FAB mass spectra of 1-12 with alkali metal ions $\left(\mathrm{Li}^{+}, \mathrm{Na}^{+}, \mathrm{K}^{+}, \mathrm{Rb}^{+}\right.$, and $\left.\mathrm{Cs}^{+}\right)$ showed formation of abundant metal-coordinated ions $\left([\mathrm{M}+\mathrm{Met}]^{+}\right.$and $\left[\mathrm{TC}_{2} \mathrm{H}_{4}+\mathrm{Met}^{+}\right)$. Compounds $3,4,6,7$, and 10-12 showed ions due to the substitution of the thymine moiety by a hydroxyl group $\left([\mathrm{M}+\text { Met }-108]^{+}\right.$, Met = metal ion). For compound 3 alone, substitution of two thymine groups $\left([\mathrm{M}+\mathrm{Met}-216]^{+}\right)$was observed. Metastable ion studies were used to elucidate the structures of these potentially significant ions, and the ion formule were confirmed with high resolution measurements. Selectivity toward metal complexation with ligand size was seen in the T-n-T and A-n-T series and was even more pronounced in A-n-T series. These dinucleotide analogs fall in the following order of chelation of alkali metal ions, acyclic glymes < dinucleotide analogs (acyclic glymes substituted with nitrogen bases) $<$ crown ethers, which places them in perspective as receptor models. (J Am Soc Mass Spectrom 1996, 7, 42-49)
\end{abstract}

A lkali metal ions, especially $\mathrm{Na}^{+}$and $\mathrm{K}^{+}$, interact with a variety of biologically important macromolecules such as peptides, proteins, and nucleic acids, that aid in transportation through cell membranes [1]. The unusual ability of acyclic and cyclic polyethers to act as polydentate complexing agents represents a field of great chemical and biological interest for studies with inorganic cations [2]. Proton affinity measurements of polyethers are made in solution by assuming that the proton has significant dicoordinate hydrogen bonding interaction [3]. Kabarle and co-workers [4] measured gas phase basicities of glymes and crown ethers, also based on an assumption that the proton is dicoordinate. Thus, there may be analogs in the coordination of metal cations with that observed for protonations.

Polyethers that contain 5-10 oxygen atoms have the anomalous property that they form relatively stable and selective complexes with alkali and alkaline earth metals [2a, 3]. Metal ion complexation with polyethers

Address reprint requests to Dr. Jack M. Miller, Department of Chemistry, Brock University, St. Catharines, Ontario L2S 3A1, Canada. occurs in accordance with the relative size of the cation and polyether rings [5]. The discriminating capacity of a macrocyclic ring system toward binding with guest molecules has been of interest to many chemists [6]. The stability constants for 18-Crown-6 are 3-6 in methanol for $\mathrm{Na}^{+}, \mathrm{K}^{+}$, and $\mathrm{Cs}^{+}$, whereas for pentaglyme they are 1.5-2.2 [5, 7]. The difference in stability of $[\mathrm{M}+\mathrm{K}]^{+}$complexes with nitrogen and oxygen bases $\left[\mathrm{NH}_{3}, \mathrm{CH}_{3} \mathrm{NH}_{2},\left(\mathrm{CH}_{3}\right)_{2} \mathrm{NH},\left(\mathrm{CH}_{3}\right)_{3} \mathrm{~N}, \mathrm{H}_{2} \mathrm{O}\right.$, $\left(\mathrm{CH}_{3}\right)_{2} \mathrm{O}$, and $\left.\left(\mathrm{C}_{2} \mathrm{H}_{5}\right)_{2} \mathrm{O}\right]$ is smaller than the difference between the proton affinities [8].

The gas phase permits us to measure relative cation affinities without the complications that arise from solvent or counterion effects. Recent mass spectrometric studies showed selectivity to crown ethers for alkali metal ions and antmonium ions (and their derivatives) for complexation [9]. Collision-induced dissociation (CID) of crown ether complexes with alkali metal ion and ammonium ion species also has been studied [9]. Electrospray mass spectrometry also was used to study the interaction of alkali, alkali earth, and divalent transition metal ions with crown ethers, cyclam, and Scrown [10]. The relative complexation behavior of the 
ligand tris(3,6-dioxaheptyl)amine (TDA-1) toward alkali metal cations was compared with that of crown ethers using fast-atom bombardment mass spectrometry (FABMS) [11].

More recently, Dey et al. [12] reported for the first time preferential complementary base pair formation of free nucleobases and mononucleosides in the gas phase. Mallis and Russell [13] summarized the chemistry of cluster ions of nucleotides with alkali metal ions. In our laboratory we have had an ongoing interest in the study of metal complexation and various aspects of hydrogen bonding in both condensed and gas phases by mass spectrometry. It is of interest to determine whether the type of multicoordination that is possible in solution phases also exists in the gas phase when nitrogen bases are present at both ends of polyether chain. In the present study the relative contributions of hydrogen bonding between two nucleobases and its effect on metal encapsulation with acyclic polyether nucleobase substituted glymes 1-12 (Figure 1) by using alkali metal ions in the gas phase is discussed. This forms an interaction crossover between the study of metal ion complexation by conventional ligands such as crown ethers and metal ion complexation by biological analogs.

\section{Experimental}

Compounds 1-12 were prepared from corresponding polyether dibromides. Polyether dibromides were synthesized from the corresponding glycols via literature procedures [14]. Thymine alkylation was carried out via the method reported [15] for 1-methylthymine to
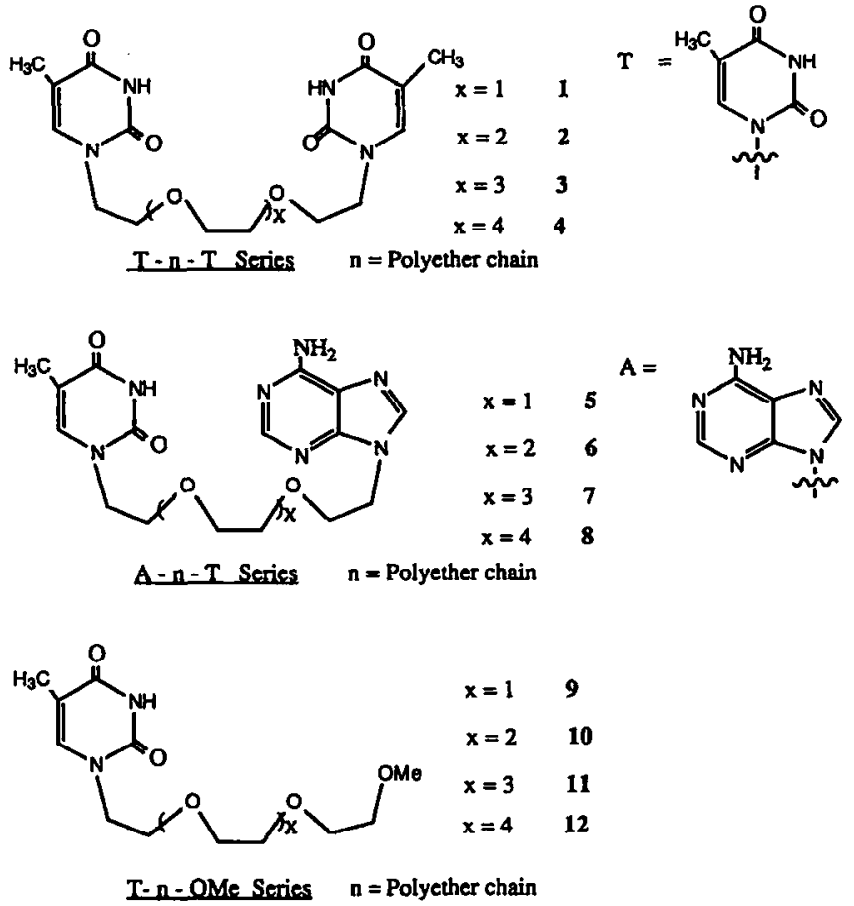

Figure 1 yield 1-4. Compounds 5-8 were synthesized from bromopolyether thymine via the procedure reported [16] for the benzylation of adenine. The same method was applied to make 9-12 by using methanol from bromopolyether thymine. Compounds 1-12 were characterized by NMR and mass spectra. 3-Nitrobenzyl alcohol (NBA), glycerol, deuterium oxide, lithium chloride (Aldrich Chemical Co., Milwaukee, WI), cesium iodide, rubidium iodide, potassium chloride, and sodium chloride (British Drug House) were used without further purification.

Fast-atom bombardment (FAB) mass spectra were recorded on a Kratos (Manchester, UK) Conçept 1S double focusing mass spectrometer (EB geometry), interfaced to a Kratos DART/MACH3 data system. The standard Concept FAB source was used with an Ion Tech (Middlesex, UK) fast-atom gun. Xenon fast atoms generated with 6-8 kV and 1-mA emission current were used for bombardment. The pressure at the source gauge was $1-2 \times 10^{-5}$ torr. Samples dissolved in matrix were placed on the 1-mm-diameter stainless steel probe tips. The source was operated at room temperature. An $8-\mathrm{kV}$ accelerating potential was used at a resolving power of 1000 for low resolution spectra measurement and 12,000 and $7000(\mathrm{~m} / \mathrm{z} 376$ from 6 and 379 from 1) for exact mass determination. The data system was calibrated with 2,4,6-tris(perfluoroheptyl)1,3,5-triazine, and spectra were acquired, averaged, and the matrix background was subtracted by using the data system. Helium was used as the collision gas in the first field-free region collision cell for recording collision-activated dissociation (CAD) spectra. The pressure of helium was adjusted to reduce the main beam intensity by $40-45 \%$ of its original value. Daughter ion and precursor ion spectra were recorded by use of linked scans at constant $B / E$ and $B^{2} / E$, respectively. Multiple scans were accumulated in each experiment and runs were repeated at least twice to check the reproducibility.

\section{Results and Discussion}

\section{Fast-Atom Bombardment Mass Spectrometry of Compounds 1-12}

Compounds 1-12 were analyzed under FAB conditions by using NBA as the matrix (Table 1). Compounds 1-12 formed the common ions $\left[\mathrm{M}+\mathrm{H}^{+}\right.$, $\left[\mathrm{TC}_{2} \mathrm{H}_{4}\right]^{+},\left[\mathrm{T}-\mathrm{CH}_{3}\right]^{+}, \mathrm{M}^{+*},\left[\mathrm{M}+\mathrm{H}-\mathrm{H}_{2}\right]^{+}$, and $\left[\mathrm{M}+\mathrm{H}-\mathrm{C}_{2} \mathrm{H}_{4} \mathrm{O}\right]^{+}$. The $\left[\mathrm{TC}_{2} \mathrm{H}_{4}\right]^{+}$ion is most abundant for 1-4. Compounds 3, 4, 6, and 7 gave the unexpected ion $[\mathrm{M}+\mathrm{H}-108]^{+}$whose origin will be discussed later. Formation of $\left[\mathrm{MH}-\mathrm{C}_{2} \mathrm{H}_{4} \mathrm{O}\right]^{+}$ion is more pronounced for compounds 6 and 7. Loss of $\mathrm{C}_{2} \mathrm{H}_{4} \mathrm{O}$ units from the molecular ion is also a characteristic feature of other cyclic polyethers under electron ionization [17].

Formation of $\left[\mathrm{M}+\mathrm{H}-\mathrm{C}_{2} \mathrm{H}_{4} \mathrm{O}\right]^{+}$ions can be attributed to the fact that the $\mathrm{H}$ bonding between two 
Table 1. Partial mass spectra of compounds 1-12 obtained under FAB with NBA matrix (relative abundances are given)

\begin{tabular}{|c|c|c|c|c|c|c|c|c|c|c|c|c|}
\hline & \multicolumn{12}{|c|}{ Compound number } \\
\hline & 1 & 2 & 3 & 4 & 5 & 6 & 7 & 8 & 9 & 10 & 11 & 12 \\
\hline$[\mathrm{T}-\mathrm{CH} 3]^{+}$ & 17 & 16 & 15 & 16 & 5 & 9 & 6 & 20 & 14 & 11 & 22 & 5 \\
\hline$[\mathrm{AH}]^{+}$ & & & & & 10 & 25 & 30 & 32 & & & & \\
\hline$[\mathrm{TH}]^{+}$ & 8 & 7 & 6 & 7 & 3 & 4 & 2 & 3 & 7 & 6 & 12 & 4 \\
\hline $\begin{array}{l}{\left[\mathrm{TC}_{2} \mathrm{H}_{4}\right]^{+}} \\
{\left[\mathrm{AC}_{2} \mathrm{H}_{4}\right]^{+}}\end{array}$ & 100 & 100 & 100 & 100 & $\begin{array}{l}12 \\
11\end{array}$ & $\begin{array}{l}22 \\
23\end{array}$ & $\begin{array}{l}15 \\
27\end{array}$ & $\begin{array}{l}58 \\
43\end{array}$ & 100 & 71 & 100 & 16 \\
\hline $\begin{array}{l}{\left[\mathrm{TC}_{4} \mathrm{H}_{8} \mathrm{O}\right]^{+}} \\
{\left[\mathrm{AC}_{4} \mathrm{H}_{8} \mathrm{O}\right]^{\prime}}\end{array}$ & 4 & 4 & 4 & 5 & 5 & 9 & 12 & 14 & 4 & 4 & 11 & 3 \\
\hline$[\mathrm{M}]^{+\cdot}$ & 6 & 6 & 4 & 5 & 13 & 10 & 8 & 7 & 5 & 10 & 8 & 2 \\
\hline$[\mathrm{M}+\mathrm{H}]^{+}$ & 51 & 54 & 20 & 50 & 100 & 100 & 15 & 100 & 46 & 50 & 82 & 9 \\
\hline$\left[\mathrm{M}+\mathrm{H}-\mathrm{C}_{2} \mathrm{H}_{4} \mathrm{O}\right]^{+}$ & 2 & 3 & 1 & 5 & 5 & 22 & 27 & 3 & 2 & 5 & 5 & 2 \\
\hline$\left[\mathrm{M}+\mathrm{H}-\mathrm{NHCO}^{+}\right.$ & 3 & 7 & 2 & 1 & & & & & & & & \\
\hline$[2 \mathrm{M}+\mathrm{H}]^{+}$ & 3 & 2 & & & 3 & 1 & & & & & & \\
\hline$[M+H-108]^{+}$ & & & 12 & 5 & & 23 & $30^{B}$ & & & 50 & 7 & $100^{a}$ \\
\hline$[\mathrm{M}-\mathrm{H}]^{+}$ & 2 & 3 & 2 & 2 & 8 & $\begin{array}{l}10 \\
16^{b}\end{array}$ & $\begin{array}{l}9 \\
24^{b}\end{array}$ & 2 & 13 & 8 & 13 & 2 \\
\hline Other ions & $9^{c}$ & $5^{c}$ & & & $7^{c}$ & $8^{c}$ & $100^{d}$ & & $70^{\circ}$ & $\begin{array}{l}93^{e} \\
100^{\prime}\end{array}$ & $65^{e}$ & $\begin{array}{l}32^{e} \\
40^{d}\end{array}$ \\
\hline
\end{tabular}

$\mathrm{a}+\mathrm{M}+\mathrm{Na}-108]^{+}$

$\left[\mathrm{M}+\mathrm{H}-\mathrm{H} 2,-\mathrm{C}_{2} \mathrm{H}_{4} \mathrm{O}\right]^{+}$

c $[2 \mathrm{M}+\mathrm{H}-\mathrm{Thy}]^{+}$.

$\left.{ }^{d} \mathrm{M}+\mathrm{Na}\right]^{+}$.

${ }^{\theta}\left[\mathrm{C}_{2} \mathrm{H}_{4} \mathrm{OMe}\right]^{+}$

' $[\mathrm{M}+\mathrm{H}-94]^{+}$.

nucleobases initially holds together the two fragments that result from expulsion of one $\mathrm{C}_{2} \mathrm{H}_{4} \mathrm{O}$ unit from polyether chains. The formula of $\left[\mathrm{M}+\mathrm{H}-\mathrm{C}_{2} \mathrm{H}_{4} \mathrm{O}\right]^{+}$ ion was confirmed by high resolution measurements $\left(\mathrm{C}_{16} \mathrm{H}_{22} \mathrm{~N}_{7} \mathrm{O}_{4}\right.$; theoretical, 376.1733; observed, 376.1718; $\Delta=3.6 \mathrm{ppm}$ ). $\mathrm{H}$ bonds between $\mathrm{A}$ and $\mathrm{T}$ are stronger than those for T-T [18]. In the present study, this is reflected in the formation of less abundant $[\mathrm{M}+\mathrm{H}-$ $\left.\mathrm{C}_{2} \mathrm{H}_{4} \mathrm{O}\right]^{+}$ions from 1-4. The $[\mathrm{M}+\mathrm{H}]^{+}$ion is more abundant in A-n-T compared to T-n-T, and can be attributed to the higher proton affinity of adenine moiety [19]. Compounds 1 and 2 form proton-bound dimers and loss of a thymine neutral molecule (126 u) from the $[2 \mathrm{M}+\mathrm{H}]^{+}$ion is observed $([2 \mathrm{M}+\mathrm{H}-$ Thy] $^{+}$). Compounds 5 and 6 whose polyether chain is similar to compounds 1 and 2, respectively, also gave $[2 \mathrm{M}+\mathrm{H}]^{+}$and $\left[2 \mathrm{M}+\mathrm{H}-\right.$ Thy $^{+}$ions.

During the preparation of A-n-T and T-n-OMe, the use of $\mathrm{NaH}$ resulted in contamination of the products with small quantities of sodium ions. This led to the formation of $[\mathrm{M}+\mathrm{Na}]^{+}$ions. The spectrum of compound 7 showed the $[\mathrm{M}+\mathrm{Na}]^{+}$ion as the most abundant species. This is not unexpected, because cationization with an alkali metal ion often gives a more intense FAB spectrum than that of the free ligand. Common ions produced from 9-12 under $\mathrm{FAB}$ conditions with a NBA matrix are $[\mathrm{M}+\mathrm{H}]^{+},\left[\mathrm{TC}_{2} \mathrm{H}_{4}\right]^{+}$, and $\left[\mathrm{C}_{2} \mathrm{H}_{4} \mathrm{OMe}\right]^{+}$and the most abundant ion is $\left[\mathrm{TC}_{2} \mathrm{H}_{4}\right]^{+}$. Compound 12 gave the $[\mathrm{M}+\mathrm{Na}-108]^{+}$ion $(100 \%)$, whereas 10 gave $(\mathrm{M}+\mathrm{H}-94)^{+}$as the most abundant ion in addition to the common ions.

The negative ion FAB mass spectra of 1-8 showed the $[\mathrm{M}-\mathrm{H}]^{-}$ion as the most abundant species. The other prominent ions in the spectra of 1-4 are at $\mathrm{m} / \mathrm{z}$
125 and ions formed by the losses of $\mathrm{C}_{2} \mathrm{H}_{4} \mathrm{O}$ units from $[\mathrm{M}-\mathrm{H}]^{-}$ions. A cluster ion with NBA also is observed. For 1 and 2, ions formed by losses of neutral thymine from the $[2 \mathrm{M}-\mathrm{H}]^{-}$ion are significant. The $[\mathrm{M}-\mathrm{H},-108]^{+}$ion is observed also for 3 . The similar ion in positive mode is the $[\mathrm{M}+\mathrm{H}-108]^{+}$ion. High yields of $[\mathrm{M}-\mathrm{H}]^{-}$ions [20] from compounds 1-8 are due to the stabilization of $[\mathrm{M}-\mathrm{H}]^{-}$ions with $\mathrm{H}$ bonding between two nucleobases. In addition to [M $-\mathrm{H}]^{-}$ions from 5-8, ions at $m / z \quad 125$ and 134 are seen also. However, the ions $[2 \mathrm{M}-\mathrm{H},-$ thymine or adenine) ${ }^{-}$are not observed for $\mathbf{5}$ and $\mathbf{6}$ unlike for $\mathbf{1}$ and 2. $T-n-T$ compounds give greater absolute ion abundances in the negative ionization mode compared to A-n-T samples for equimolar amounts of sample. Compounds 5-8 are more basic in nature than 1-4 and this is reflected in the lower intensity of the A-n-T spectra because the proton affinity of adenine ( 939.7 $\mathrm{kJ} / \mathrm{mol}$ ) is greater than the proton affinity of thymine $(882.4 \mathrm{~kJ} / \mathrm{mol}$ ) [19]. The mass spectra of $\mathbf{9}$ and $\mathbf{1 1}$ also have the $[\mathrm{M}-\mathrm{H}]^{-}$ion as most abundant species and an ion at $m / z 125$ from the thymine unit minus one hydrogen is also observed under negative ion FAB conditions.

\section{Fast-Atom Bombardment Mass Spectrometry of $T-n-T$ with Metal Ions}

Compounds 1-4 were investigated by using the full series of alkali metal ions $\left(\mathrm{Li}^{+}, \mathrm{Na}^{+}, \mathrm{K}^{+}, \mathrm{Rb}^{+}\right.$, and $\mathrm{Cs}^{+}$) in a NBA matrix. All compounds of this type chelate well with metal ions. However, large negative entropies in $\left[\mathrm{R}-\mathrm{NH}_{3}\right]^{+}$-acyclic ether complexes versus $\left[\mathrm{R}-\mathrm{NH}_{3}\right]^{+}$-cyclic crown ethers make the acyclic 
polyethers less effective ligands for complexation [21]. In compounds 1-4, there is a probability for the existence of cyclic form due to $\mathrm{H}$ bonding between the nucleobases at the ends of the acyclic polyether chain. This might be responsible for effective complexation of metal ions. The presence of more basic sites in analytes (1-4) leads to the ready formation of $[\mathrm{M}+\mathrm{H}]^{+}$ion. Common ions produced in the spectra of 1-4 with significant abundances are $[\mathrm{M}+\mathrm{Met}]^{+}(\mathrm{Met}=$ alkali metal ion), $[\mathrm{M}+\mathrm{H}]^{+},\left[\mathrm{TC}_{2} \mathrm{H}_{4}+\mathrm{Met}\right]^{+},\left[\mathrm{TC}_{2} \mathrm{H}_{4}\right]^{+}$, and $\left[\mathrm{T}-\mathrm{CH}_{3}\right]^{+}$. The ion $\left[\mathrm{TC}_{2} \mathrm{H}_{4}\right]^{+}$can arise by the cleavage of the $\mathrm{C}-\mathrm{O}$ bond $\beta-$ to the thymine ring. This species, plus a metal ion, gave rise to $\left[\mathrm{TC}_{2} \mathrm{H}_{4}+\right.$ $\mathrm{Met}]^{+}$ion, and the abundance of this ion is increased by increasing the amount of metal halide. This also suggests that the metal ion can chelate through the thymine carbonyl oxygen. With an excess of metal halide present during the recording of the FAB spectra, all T-n-T compounds showed the $\left[\mathrm{TC}_{2} \mathrm{H}_{4}+\mathrm{Met}\right]^{+}$ion as the most abundant species. Under these conditions, all $\mathrm{T}-\mathrm{n}-\mathrm{T}$ compounds showed ions $[\mathrm{M}+2 \mathrm{Met}-\mathrm{H}]^{+}$ and $[\mathrm{M}+3 \mathrm{Met}-2 \mathrm{H}]^{+}$in significant abundances. The most abundant anomalous ions $[\mathrm{M}+\mathrm{Met}-108]^{+}$and $[\mathrm{M}+\mathrm{Met}-216]^{+}$were seen only in 3 , whereas in 4 only the former ion is present in addition to common ions in the spectra. The mass spectrum of compound 3 obtained with $\mathrm{KCl}$ and $\mathrm{NaCl}$ (in 1:1:1 and 1:2:2 ratio) together showed participation of both $\mathrm{Na}^{+}$and $\mathrm{K}^{+}$ ions in the formation of $[\mathrm{M}+\mathrm{Met}]^{+}$ions with equal abundances. Ions that arise from loss of $108 \mathrm{u}$ also are observed from the metal-containing ions.

Possible fragment ions in the spectra of 1-4 recorded with alkali metal ions are given in Table 2, which shows selected data, where the metal ion is incremented with the increase in the size of the ether unit. Experiments were carried out for $\mathrm{T}-\mathrm{n}-\mathrm{T}$ with standard solutions of analytes (1-4) in NBA and metal halides in water. When analyte and metal halide are in a 1:1 mole ratio, $[\mathrm{M}+\mathrm{H}]^{+}$and $[\mathrm{M}+\mathrm{Met}]^{+}$ions are usually both abundant as was $\left[\mathrm{TC}_{2} \mathrm{H}_{4}\right]^{+}$. Other ions also observed for 1 are $[\mathrm{M}+2 \mathrm{Li}-\mathrm{H}]^{+},[\mathrm{M}+3 \mathrm{Li}-2 \mathrm{H}]^{+}$, and $[2 \mathrm{M}+\mathrm{Li}-\text { Thy }(126)]^{+}$, and less abundant ions are seen at $m / z 739,745,751,757$, and 763. These cluster ions are $\left[2 \mathrm{M}+\mathrm{Li}_{x}-\mathrm{H}(x-1)\right]^{+}$, where $x=$ $1-5$. They are formed by displacement of one amide proton by the metal ion from the $[2 \mathrm{M}+\mathrm{Li}]^{+}$ion and the same process is observed for monomers also. Experiments carried out by using $\mathrm{D}_{2} \mathrm{O}$ and $\mathrm{LiCl}$ with 1

Table 2. Partial FAB mass spectra of 1-12 with metal ions ( $\mathrm{Li}^{+}, \mathrm{Na}^{+}, \mathrm{K}^{+}$, and $\mathrm{Rb}^{+}$) and $\mathrm{NBA}$ matrix (relative abundances are given)

\begin{tabular}{|c|c|c|c|c|c|c|c|c|c|c|c|c|}
\hline & \multicolumn{12}{|c|}{ Compound number and metal ion } \\
\hline & $\begin{array}{c}1 \\
\mathrm{Li}^{+}\end{array}$ & $\mathrm{Na}^{2}$ & $\mathrm{~K}^{\mathbf{3}}$ & $\begin{array}{c}4 \\
R b^{+}\end{array}$ & $\begin{array}{c}5 \\
\mathrm{Li}^{+}\end{array}$ & $\frac{6}{\mathrm{Na}^{+}}$ & $\underset{\mathrm{Na}^{+}}{7}$ & $\begin{array}{c}8 \\
R_{b^{+}}\end{array}$ & $\begin{array}{c}9 \\
\mathrm{Li}^{+}\end{array}$ & $\begin{array}{c}10 \\
\mathrm{Na}^{+}\end{array}$ & $\begin{array}{l}11 \\
\mathrm{~K}^{+}\end{array}$ & $\begin{array}{c}12 \\
R^{+}\end{array}$ \\
\hline$\left[\mathrm{T}-\mathrm{CH}_{3}\right]^{+}$ & 11 & 17 & 6 & 16 & 5 & 17 & 6 & 16 & 3 & 3 & 16 & 16 \\
\hline$[\mathrm{AH}]^{+}$ & & & & & 11 & 34 & 28 & 22 & & & & \\
\hline$\left[\mathrm{TC}_{2} \mathrm{H}_{4}\right]^{+}$ & 54 & 100 & 22 & 75 & 7 & 37 & 17 & 41 & 7 & 11 & 88 & 5 \\
\hline$\left[\mathrm{AC}_{2} \mathrm{H}_{4}\right]^{+}$ & & & & & 9 & 42 & 24 & 32 & & & & \\
\hline$\left[\mathrm{TC}_{2} \mathrm{H}_{4}+\mathrm{Met}^{+}\right.$ & 83 & 29 & 29 & 63 & 100 & 16 & 58 & 30 & 15 & 18 & 4 & 47 \\
\hline$[\mathrm{M}+\mathrm{H}]^{+}$ & 32 & 56 & 7 & 20 & 19 & 100 & 22 & 43 & 2 & 6 & 48 & 1 \\
\hline$\left[\mathrm{M}+\mathrm{Met}^{+}\right.$ & 100 & 69 & 30 & 100 & 69 & 29 & 100 & 100 & 100 & 66 & 100 & 48 \\
\hline$[\mathrm{M}+2 \mathrm{Met}-\mathrm{H}]^{+}$ & 44 & 5 & 9 & 9 & 22 & 6 & 11 & 14 & 36 & 8 & 3 & 11 \\
\hline$[\mathrm{M}+3 \mathrm{Met}-2 \mathrm{H}]^{+}$ & 17 & 2 & 4 & 2 & & & & & & & & \\
\hline$[M+\text { Met }-108]^{+}$ & & & 100 & 15 & & 15 & 27 & 3 & & 34 & 19 & 100 \\
\hline$\left[\mathrm{M}+\mathrm{Met}-\mathrm{C}_{2} \mathrm{H}_{4} \mathrm{O}\right]^{+}$ & 3 & 3 & 2 & 8 & 2 & 6 & 15 & 4 & & 3 & 3 & 3 \\
\hline$\left[\mathrm{M}+\mathrm{H}-\mathrm{H}_{2}\right]^{+}$ & 6 & 9 & 3 & 5 & 3 & 18 & 2 & 7 & & 2 & 2 & \\
\hline Other lons & $12^{a}$ & $9^{a}$ & & & & $25^{3}$ & & & $11^{\mathrm{b}}$ & $100^{c}$ & & \\
\hline & $2^{b}$ & $2^{t}$ & & & $1^{d}$ & $9^{8}$ & & & $g^{f}$ & $11^{1}$ & $22^{i}$ & $38^{i}$ \\
\hline & $4^{g}$ & $5^{h}$ & $30^{i}$ & & $2^{9}$ & $34^{i}$ & $26^{i}$ & & & & & \\
\hline & $3^{k}$ & & & & $2^{k}$ & $31^{\prime}$ & $25^{\prime}$ & & & & & \\
\hline & $2^{m}$ & & & & & $25^{n}$ & & & & & & \\
\hline & $1^{\circ}$ & & & & & & & & & & & \\
\hline
\end{tabular}

\footnotetext{
${ }^{a}[2 M+\text { Met }- \text { Thy }]^{+}$.

h $[\mathrm{M}+\mathrm{Met}-\mathrm{NHCO}]^{+}$

$c[M+\text { Met }-94]^{+}$

$[2 \mathrm{M}+\mathrm{Met}]^{+}$.

$\left[2 \mathrm{M}+\mathrm{H}-\right.$ Thy $^{+}$

${ }^{t}\left[\mathrm{C}_{2} \mathrm{H}_{4} \mathrm{OMe}^{+}\right.$.

$9\left[2 \mathrm{M}+2 \mathrm{Met}-\mathrm{H}^{+}\right.$

${ }^{h}\left[\mathrm{M}+\mathrm{H}-\mathrm{C}_{2} \mathrm{H}_{4} \mathrm{O}\right]^{+}$

$[\mathrm{M}+\mathrm{Met}-216]^{+}$

$\left[\mathrm{M}+\mathrm{H}-\mathrm{C}_{2} \mathrm{H}_{4} \mathrm{O}\right]^{+}$.

k $[2 \mathrm{M}+3 \mathrm{Met}-2 \mathrm{H}]^{+}$.

' $\left.\mathrm{M}+\mathrm{H}-\mathrm{H} 2,-\mathrm{C}_{2} \mathrm{H}_{4} \mathrm{O}\right]^{+}$

$m_{[2 M+4 M e t}-3 \mathrm{H}^{+}$.

$n[\mathrm{M}+\mathrm{H}-108]^{+}$.

${ }^{\circ}[2 \mathrm{M}+5 \mathrm{Met}-4 \mathrm{H}]^{+}$
} 
showed that metal ions and deuterium ions displace exchangeable amide protons $\{\mathrm{CONHCO}$ and shift the $\left[\mathrm{M}+\mathrm{Li}^{+}\right.$ion by $2 \mathrm{u}$ to $\mathrm{m} / \mathrm{z} 375$ and the $[\mathrm{M}+2 \mathrm{Li}-$ $\mathrm{H}]^{+}$ion by $1 \mathrm{u}$; the $[\mathrm{M}+3 \mathrm{Li}-2 \mathrm{H}]^{+}$ion is not shifted from its original position at $m / z 385$. Similarly, mass shifts in the formation of $[2 \mathrm{M}+\mathrm{Met}]^{+}$ions due to the presence of amide protons in particular ions also are seen in the spectra. This verifies the displacement of amide protons by the metal ions. The formula of the 379 ion $\left([\mathrm{M}+2 \mathrm{Li}-\mathrm{H}]^{+}\right)\left(\mathrm{C}_{16} \mathrm{H}_{21} \mathrm{~N}_{4} \mathrm{O}_{6} \mathrm{Li}_{2}\right.$ : theoretical, 379.17812; observed, 379.17888; $\Delta=2.0 \mathrm{ppm}$ ) from compound 1 is confirmed with high resolution measurements. The metastable ion spectrum of $\mathrm{m} / \mathrm{z} 379$ from 1 showed the formation of ions by losses of $(\mathrm{NLiCO})$ and $(\mathrm{NHCO})$ moieties from the parent ion. This indicates the displacement of the amide proton of thymine ring by alkali metal ion. Alkali metal ions, which do not deprotonate amides in solution [22], are capable of displacment of amide protons in the FAB experiment.

\section{Fast-Atom Bombardment Mass Spectrometry A-n-T-Metal Halides}

The positive ion FAB spectra of 5 8 with alkali metal ions showed $[\mathrm{M}+\mathrm{Met}]^{+},[\mathrm{M}+\mathrm{H}]^{+},\left[\mathrm{TC}_{2} \mathrm{H}_{4}\right]^{+}$, $\left[\mathrm{T}-\mathrm{CH}_{3}\right]^{+},\left[\mathrm{TC}_{2} \mathrm{H}_{4}+\mathrm{Met}\right]^{+},\left[\mathrm{AC}_{2} \mathrm{H}_{4}\right]^{+}$, and $[\mathrm{M}+$ $2 \mathrm{Met}-\mathrm{H}]^{+}$ions in all these spectra (Table 2). The spectrum of 5 , with an excess of metal halides, shows the $\left[\mathrm{TC}_{2} \mathrm{H}_{4}+\mathrm{Li}\right]^{+}$ion as the most abundant species, and ions due to displacement of the amide $\mathrm{NH}$ protons by metal ions are observed for monomers and dimers at $m / z 388,763$, and 769 . One interesting point is that only the amide hydrogen is replaced, not the $\mathrm{H}$ of the amine group present in the adenine moiety in both monomer and dimer. Production of $[\mathrm{M}+\mathrm{H}-$ $\mathrm{C}_{2} \mathrm{H}_{4} \mathrm{O}^{+}$and $\left[\mathrm{M}+\mathrm{Met}-\mathrm{C}_{2} \mathrm{H}_{4} \mathrm{O}\right]^{+}$ions are a sign of formation of $\mathrm{H}$ bonding between $\mathrm{A}$ and $\mathrm{T}$ bases. Because 7 compound was contaminated with $\mathrm{Na}^{+}$ during its preparation, the FAB spectra were recorded with $\mathrm{Na}^{+}$. The ion that corresponds to [M+ Met $108]^{+}$is present in 7 , but this ion is not that abundant in compounds 4,6 , and 7 and is absent in 8 . In 3 , it is the most abundant ion irrespective of the chelated metal ion. The formation and higher abundance of ion $[\mathrm{M}+\text { Met }-108]^{+}$from 3 is attributed to the existence of different molecular conformations for each compound.

The linked scan at constant $B / E$ of the $[\mathrm{M}+\mathrm{Rb}]^{+}$ ion from 8 showed formation of the rubidium ion as the principal process, whereas the fragmentation of the $[\mathrm{M}+\mathrm{Li}]^{+}$ion of compound 5 gave [Add -43$]^{+}$ (Add $=$ adduct) and [Add $-126(\text { Thy) }]^{+}$, followed by losses of two $\mathrm{C}_{2} \mathrm{H}_{4} \mathrm{O}$ units and one $\mathrm{C}_{2} \mathrm{H}_{3} \mathrm{O}$ unit. Hydrogen losses from the adenine moiety, $\left[\mathrm{TC}_{2} \mathrm{H}_{5}\right]^{+}$ and $\left[\mathrm{TC}_{2} \mathrm{H}_{4} \mathrm{O}\right]^{+}$ions also are observed. The $\left[\mathrm{TC}_{2} \mathrm{H}_{3}+\right.$ $\mathrm{Li}]^{+}$ion is the most abundant species observed. The metastable ion spectrum of the $[\mathrm{M}+\mathrm{Met}]^{+}$ion of 4 $\left(\right.$ Met $=\mathrm{Cs}^{+}$or $\left.\mathrm{Rb}^{+}\right)$in the first field-free region showed formation of metal ions as the dominant process of fragmentation and other less prominent ions that corresponds to [Add $-\mathrm{H}]^{+}$and [Add -14$]^{+}$ions. The metastable ion spectra of 1 and 2 gave [Add $14]^{+},[\text {Add }-\mathrm{NHCO}]^{+}$, and [Add -126$]^{+}$ions, followed by losses of $\mathrm{C}_{2} \mathrm{H}_{4} \mathrm{O}$ units. However, the metastable ion spectra of 3,4 , and 8 with larger-sized metal ions produced metal ions as the major process. The linked scan spectrum of 3 at constant $B / E$ with $\mathrm{KCl}$ gave fragment ions from the polyether chain. A common feature observed in the first field-free region (FFR) decomposition studies of adduct ions, either from $T-n-T$ compounds or from A-n-T compounds, is that adduct ions with larger cations preferred to decompose to metal cations whereas adducts with smaller cations preferred to produce ions from fragmentation of the analyte species as previously observed [23]. This observation can be attributed to size of the cavity and metal ion. The cavity size of compounds 3,4 , and 8 can accommodate smaller cations, whereas larger cations, must coordinate either from the bottom or from the top of the cavity of polyether analogs [10].

Experiments carried out with equimolar solutions of $\mathrm{LiCl}$ and $\mathrm{RbI}$ with 1, 4, 5 and 8 showed selectivity toward complexation of metal ions. The compound 1 formed the $\left[\mathrm{M}+\mathrm{Li}^{+}\right.$ion with $23 \%$ intensity and the $[M+R b]^{+}$ion with $18 \%$ intensity, whereas 4 gave the $[\mathrm{M}+\mathrm{Li}]^{+}$ion with a $9 \%$ intensity and the $[\mathrm{M}+\mathrm{Rb}]^{+}$ ion with $22 \%$ intensity. Chelation through the carbonyl oxygen of thymine $\left(\left[\mathrm{TC}_{2} \mathrm{H}_{4}+\mathrm{Met}\right]^{+}\right)$dominated the spectrum of 1 because of the larger size of the cation. Similarly, 5 forms $\left[\mathrm{M}+\mathrm{Li}^{+}\right.$ion (49\%), whereas [M+ $\mathrm{Rb}]^{+}$ion is only $8 \%$ abundant, whereas 8 formed the $[\mathrm{M}+\mathrm{Li}]^{+}$ion with $13 \%$ relative abundance versus the $[\mathrm{M}+\mathrm{Rb}]^{+}$ion with $24 \%$. Based on the relative abundances it can be concluded that the A-n-T series is more selective compared to $\mathrm{T}-\mathrm{n}-\mathrm{T}$ series toward metal complexation. The two $\mathrm{H}$ bonds between $\mathrm{A}$ and $\mathrm{T}$ are stronger and keep the cavity size more rigid.

\section{Fast-Atom Bombardment Mass Spectrometry of T-n-OMe with Metal Halides}

FAB mass spectra of $\mathrm{T}-\mathrm{n}$-OMe recorded with alkali metal ions contain the common ions $[\mathrm{M}+\mathrm{H}]^{+},[\mathrm{M}+$ Met $]^{+},[\mathrm{M}+2 \mathrm{Met}-\mathrm{H}]^{+},\left[\mathrm{TC}_{2} \mathrm{H}_{4}+\mathrm{Li}\right]^{+},\left[\mathrm{TC}_{2} \mathrm{H}_{4}\right]^{+}$, and $\left[\mathrm{C}_{2} \mathrm{H}_{4} \mathrm{OMe}\right]^{+}$(Table 2). The formation of these unusual $[\mathrm{M}+\mathrm{Na}-94]^{+}$and $[\mathrm{M}+\mathrm{Na}-108]^{+}$ions from compound 10 and $[M+\text { Met }-108]^{+}$ion from compound 12 is discussed later. However, the abundace of $[M+\text { Met }-108]^{+}$ion is not varied for $\mathbf{1 1}$ by varying the metal ions $\mathrm{K}^{+}, \mathrm{Rb}^{+}$, and $\mathrm{Cs}^{+}$.

The metastable ion spectrum of the $\left[\mathrm{M}+\mathrm{Na}^{+}\right.$ion of $9(\mathrm{~m} / z 295)$ is similar to the metastable ion spectrum of 10 , whereas the adduct of 11 with $\mathrm{Rb}^{+}(\mathrm{m} / z$ 
445) dissociates to give an ion at $m / z 360$ (molecular ion) and the $\mathrm{Rb}^{+}$ion in the first FFR on collision.

Formation and Structure Elucidation of

$[M+\text { Met }-108]^{+},[M+\text { Met }-216]^{+}$,

and $[M+\text { Met }-94]^{+}$Ions

Significant ions $[M+\text { Met }-108]^{+}$and $[M+$ Met $216]^{+}$are seen in the spectra of compound 3 irrespective of the size of the cation used for chelation. Observation of the formation of the $[\mathrm{M}-108]^{+}$ion under electron ionization, the $[\mathrm{M}+\mathrm{H}-108]^{+}$ion under positive ion $\mathrm{FAB}$, the $[\mathrm{M}-\mathrm{H},-108]^{-}$ion under negative ion $F A B$, and the $[M+M e t-108]^{+}$ion under positive ion $F A B$ with metal halides leads us to assume that they form from the same precursor with different clustering species that depend on the ionization mode used. Unimolecular and collision-induced dissociation studies were used to probe the structure of these ions. The metastable ion spectrum of the $[\mathrm{M}+\mathrm{Rb}]^{+}$ion from 3 did not give the ions of interest $\left([\mathrm{M}+\mathrm{Met}-108]^{+}\right.$at $\mathrm{m} / z 431$ and $[\mathrm{M}+\text { Met }-216]^{+}$ at $m / z$ 323). It showed formation of $\mathrm{Rb}^{+}$ion as the major process. The linked scan at constant $B^{2} / E$ of the 431 ion $\left([M+\text { Met }-108]^{+}\right)$showed an ion at $m / z$ 641 as the precursor. This precursor can be accounted for by addition of $\mathrm{RbOH}$ to the $[\mathrm{M}+\mathrm{Rb}]^{+}$ion. Because the analyte and matrix under FAB conditions both can be a source of hydroxy radicals [24], one can account for the addition of hydroxy radicals to metal ions. Loss of a thymine unit and $\mathrm{Rb}$ from $\mathrm{m} / z 641$ can produce an ion at $m / z 431$. Therefore, we propose that the ion at $m / z 431$ has structure a (Scheme 1). Exact mass measurements are in good agreement with pro-
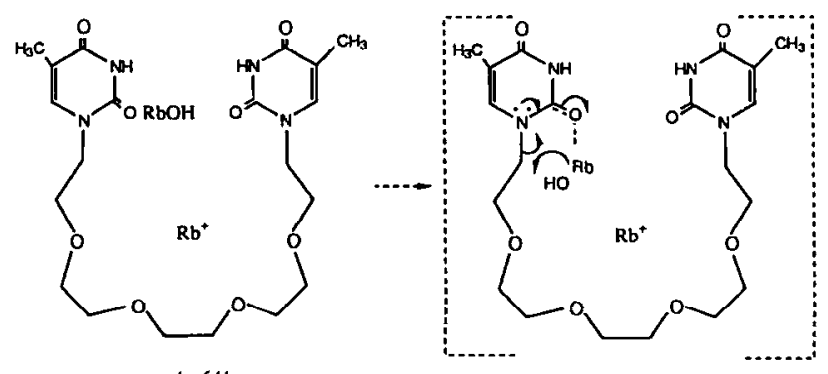

$m / 2641$

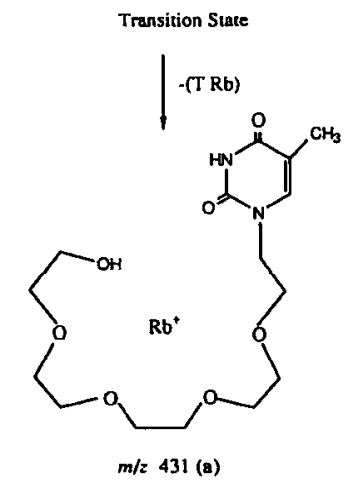

Scheme I posed molecular formula $\left(\mathrm{C}_{15} \mathrm{H}_{26} \mathrm{~N}_{2} \mathrm{O}_{7} \mathrm{Rb}\right)$ of a (theoretical, 431.08570; observed, 431.0862; $\Delta=1 \mathrm{ppm}$ ). The metastable ion spectrum of 431 produced abundant ions at $m / z 85$, rubidium ion. The ion that results from loss of $\mathrm{H}$ radicals from the 431 ion and $\left[\mathrm{HOC}_{2} \mathrm{H}_{4} \mathrm{OC}_{2} \mathrm{H}_{4}+\mathrm{Rb}\right]^{+}$ion also are observed.

The precursor ion scan of $m / z$ 323, ([M+ Met $216]^{+}$) obtained from 3 showed precursor ions at $\mathrm{m} / \mathrm{z}$ 743 and 533. Addition of two RbOH molecules to the $[\mathrm{M}+\mathrm{Met}]^{+}$ion can account for the ion at $m / z 743$. Loss of a thymine unit and one $\mathrm{Rb}$ atom can lead to the formation of the other precursor ion at $m / z 533$. This ion, on further loss of another thymine unit and a $\mathrm{Rb}$ atom, can give an ion at $m / z$ 323. Based on this observation, the ion at $m / z 323$ could have structure $\mathbf{b}$ (Scheme II). The high resolution mass measurements of this ion showed that $\mathrm{C}_{10} \mathrm{H}_{22} \mathrm{O}_{6} \mathrm{Rb}$ is a reasonable formula (theoretical, 323.05334; observed, 323.0526; $\Delta=2.2 \mathrm{ppm}$ ), which fits the proposed structure $\mathrm{b}$. Structure $\mathbf{b}$ is simply an adduct of pentaethylene glycol with $\mathrm{Rb}^{+}$. The unimolecular decomposition mass spectrum of $[M+R b]^{+}$of pentaethylene glycol and metastable ion spectrum of $\mathrm{m} / z 323$ are found to be the same. The spectra showed daughter ions at $\mathrm{m} / \mathrm{z}$ 218,216 , and 85 with significant abundances.

The formation of the parent ions and the fragmentation pathway to produce the significant ions at $\mathrm{m} / \mathrm{z}$ 431 and 323 show that in the presence of hydroxy radicals, thymine units are replaced by hydroxy radicals. Replacement of one thymine moiety with one hydroxy group is a major process, whereas the displacement of a second thymine unit by a hydroxy group is minor. The spectrum recorded with a glycerol matrix for 3 also produced abundant ions at $m / z 431$
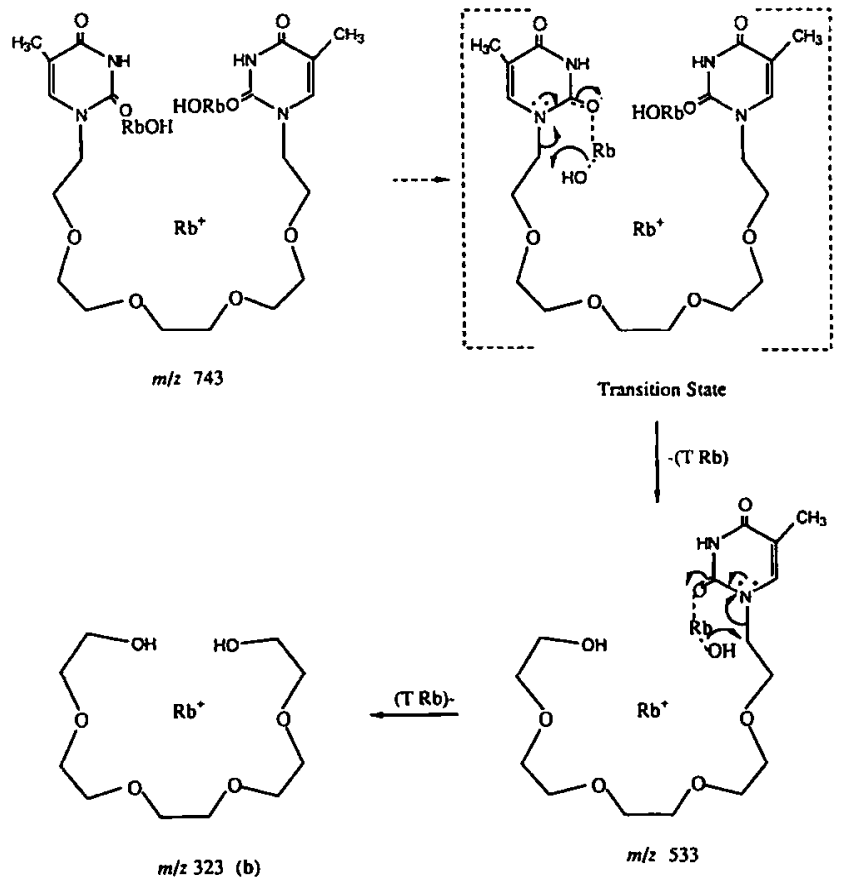

Scheme II 
and 323 with rubidium iodide. However, experiments with NBA and glycerol showed that NBA is the better matrix for the analysis of compounds 1-12.

Under electron ionization the $[\mathrm{M}-108]^{+}$ion (i.e, $m / z 346$ ) is less prominent (2\%). Addition of $\mathrm{D}_{2} \mathrm{O}$ to 3 before the EI spectrum was recorded gave ions at $\mathrm{m} / \mathrm{z}$ 347 and 348 in $4 \%$ abundance each, a shift of $1 u$ and 2 $\mathrm{u}$ from $\mathrm{m} / \mathrm{z} 346$ due to the deuterium exchange of $\mathrm{OH}$ and $\mathrm{NH}$ protons. This indicates that increased concentration of deuterated hydroxy radicals is responsible for the increased abundance of ion at $\mathrm{m} / \mathrm{z} 347$ and 348. Cleavage of the $\mathrm{N}-\mathrm{C}$ bond between the polyether chain and the thymine unit also must be considered in the formation of $m / z 346$. The $\mathrm{N}-\mathrm{C}$ bond cleavage might be facile in the presence of both protonating agents and metal halides. However, in our study, the alkali metal ions displace amide protons of the nucleobase, possibly because the alkali metal ions can also chelate through the carbonyl oxygen of the thymine unit. The behavior of the proton and alkali metal ions is analogous in the chelation we observe. Protonation and metal chelation through the carbonyl oxygen at $\mathrm{C}_{2}$ of the thymine moiety can lead to the facile cleavage of the $\mathrm{N}-\mathrm{C}$ bond, followed by addition of an $\mathrm{OH}$ group to the polyether chain. A sixmembered transition state that involves rearrangements can produce ion a as shown in Scheme I. In a similar fashion, two thymine units are substituted by two $\mathrm{OH}$ groups via a six-membered transition state in a stepwise process to give ion $\mathbf{b}$ as shown in Scheme II. Addition of $\mathrm{D}_{2} \mathrm{O}$ and $\mathrm{RbI}$ to NBA during the analysis of 3 also shifted the ion at $m / z 431$ and 323 by $2 u$.

Structures for the $[M+M e t-94]^{+}$ion from 10 and $[\mathrm{M}+\text { Met }-108]^{+}$ion from 12 are confirmed by study of these ions in the FFR. Unimolecular and CID spectra of the adduct ion of 10 at $\mathrm{m} / z 339$ did not show the formation of the ion of interest at $m / z 245$, but gave $[\mathrm{T}+\mathrm{Na}]^{+},\left[\mathrm{TCH}_{2}+\mathrm{Na}\right]^{+},\left[\mathrm{TC}_{2} \mathrm{H}_{4}+\mathrm{Na}\right]^{+}$, and $[\mathrm{M}+\mathrm{Met}-\mathrm{MeOH}]^{+}$ions. Decomposition of the ion at $m / z 245$ in the field-free region did not give ions due to thymine fragments or loss of the thymine moiety from $m / z 245$. This indicates that this ion at $m / z$ 245 does not contain the thymine unit in its structure. This ion is probably formed from the polyether chain. A linked scan spectrum at constant $B^{2} / E$ from $\mathrm{m} / \mathrm{z}$ 245 showed ions at $m / z 419$ and 302 as precursors. The ion at $m / z 419$ could have two sodium hydroxide units in excess compared to the $[\mathrm{M}+\mathrm{Na}]^{+}$ion formed from 10. Loss of two $\mathrm{Na}$ atoms followed by loss of CONHCO group from the thymine unit results in the production of another precursor ion at $\mathrm{m} / \mathrm{z}$ 302. Further fragmentation of the bond $\alpha-$ to the $\mathrm{N}$ of thymine and loss of one hydroxy group can give the ion at $\mathrm{m} / \mathrm{z}$ 245 (c) from the ion at $\mathrm{m} / z 302$ as shown in Scheme III. The metastable ion spectrum of $\mathrm{m} / z 245$ showed ions that correspond to loss of $\mathrm{CH} 4, \mathrm{MeOH}$, and $\left(\mathrm{H}_{2} \mathrm{COC}_{2} \mathrm{H}_{4} \mathrm{OMe}\right)$ and followed by $\mathrm{C}_{2} \mathrm{H}_{4} \mathrm{O}$ units losses. Exact mass measurements are in good agree-
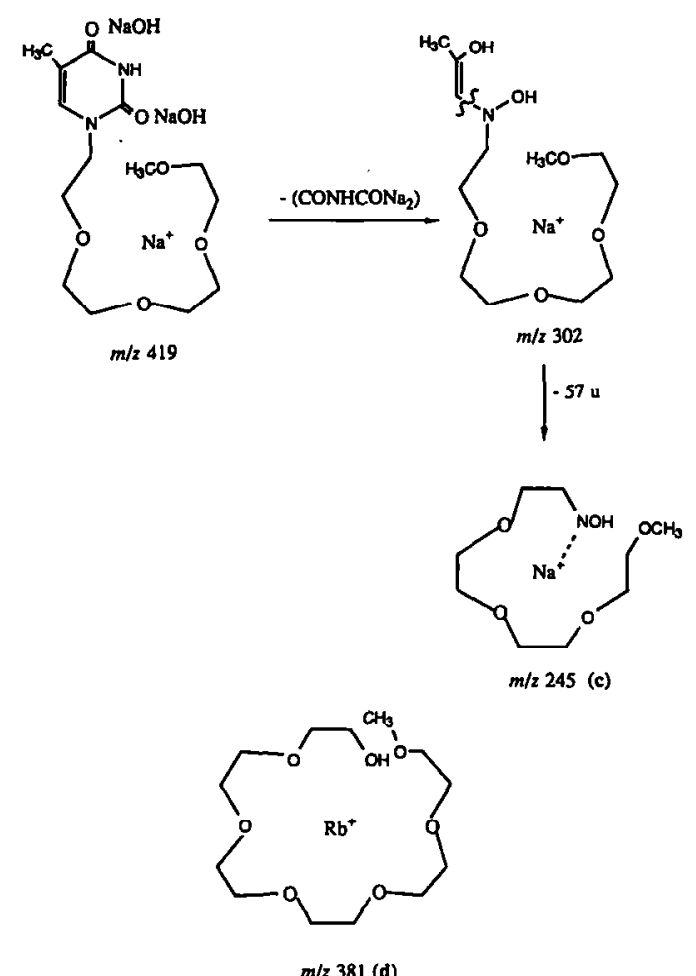

Scheme III

ment with the proposed formula $\mathrm{C}_{9} \mathrm{H}_{20} \mathrm{NO}_{5} \mathrm{Na}$ (theoretical, 245.12395; observed, 245.1247; $\Delta=3 \mathrm{ppm}$ ).

The decomposition of the $[\mathrm{M}+\mathrm{Met}]^{+}$ion of $\mathbf{1 2} \mathrm{did}$ not produce an ion at $m / z$ 381. Loss of $\mathrm{MeOH}$ from the adduct, followed by $\mathrm{C}_{2} \mathrm{H}_{4} \mathrm{O}$ units, are the major processes of fragmentation. A linked scan spectrum at constant $B^{2} / E$ of the ion at $m / z 381$ showed $m / z 591$ ion as a precursor. Addition of $\mathrm{RbOH}$ to the $[\mathrm{M}+$ $\mathrm{Met}^{+}{ }^{+}$ion gives rise to the ion at $m / z$ 591. Loss of a thymine unit and $\mathrm{Rb}$ from the $m / z 591$ ion could give an ion at $m / z$ 381. The metastable ion spectrum of $m / z 381$ does not produce ions either related to or due to loss of the thymine moiety and gave ions by the loss of $\mathrm{MeOH}$ from parent ion, followed by losses of $\mathrm{C}_{2} \mathrm{H}_{4} \mathrm{O}, \mathrm{C}_{4} \mathrm{H}_{7} \mathrm{O}_{2}$, and $\mathrm{C}_{2} \mathrm{H}_{4} \mathrm{O}$ units. Therefore, this ion originates from the polyether skeleton. The proposed structure $\mathrm{d}$ could explain the metastable ion spectrum of the ion at $m / z$ 381. High resolution mass measurements also are in good agreement with the calculated formula $\left(\mathrm{C}_{13} \mathrm{H}_{28} \mathrm{O}_{7} \mathrm{Rb}\right.$ : theoretical, 381.09520; observed, 381.0955; $\Delta=0.6 \mathrm{ppm}$ ).

\section{Electron Ionization Mass Spectrometry of Compounds 1-12.}

Compounds 1, 5, and 9-12 gave a molecular ion under electron ionization, whereas 2-4 and 6-8 did not. Compound 5 gave molecular ion at $\mathrm{m} / \mathrm{z} 375$ with significant abundance. However, formation of [M $\mathrm{NHCO}]^{+}$ion from 1 and $[\mathrm{M}-\mathrm{HCN}]^{+}$ion from 5 are not observed even though thymine is known to show loss of NHCO from the molecular ion [25] and forma- 
tion of ions at $m / z 135$ and 108 are the characteristic of 6-aminopurines [26] under electron ionization conditions. Less prominent $\left[\mathrm{M}-\mathrm{C}_{2} \mathrm{H}_{4} \mathrm{O}\right]^{+}$ions are observed from both due to the existence of intramolecular $\mathrm{H}$ bond. Compounds 9-12 produce less prominent molecular ions and an ion at $m / z 59\left(\left[\mathrm{C}_{2} \mathrm{H}_{4} \mathrm{OCH} 3\right]^{+}\right)$ is the most abundant species in all $\mathrm{T}-\mathrm{n}-\mathrm{OMe}$ compounds.

\section{Conclusion}

From this study we may conclude that these acyclic polyethers with nucleobases coordinate with alkali metal ions in a fashion similar to crown ethers. The $\mathrm{H}$ bond between the two nitrogen bases controls the ring size and affects selective complexation with metal ions. This is shown to be stronger between $A$ and $T$ than between $\mathrm{T}$ and $\mathrm{T}$, which is reflected in the expulsion of $\mathrm{C}_{2} \mathrm{H}_{4} \mathrm{O}$ units from protonated and metal chelated species and selectivity toward metal ion encapsulation as a function of the metal ion size. The nature of chelation with larger cation is different from the smaller metal ions as was shown by the CID studies of metalcomplexed ions. The unusual formation of ions due to substitution of the thymine moiety depends on the availability of hydroxy radicals and the conformation of the thymine unit and polyether chain. The substitution of only thymine, not the adenine moiety, reflects on the bond strength between the polyether chain and the nitrogen bases and on the nature of available electron-rich centers on that nitrogen base to coordinate the metal ion. For the A-n-T series the carbonyl oxygen involved in two $\mathrm{H}$ bonds and the hydrolysis of thymine is the minor process. However, for $T-n-T$ series, even though the $H$ bond exists between $T$ and $T$, it is less effective than that of $A-n-T$; thus there is more probability for coordination through the carbonyl group and displacement of thymine moiety. In general compounds 5-8 are more selective for metal ion complexation than compounds 1-4. Finally, in this work we show the utility of modified acyclic glymes (dinucleotide analogs) to serve as receptor models.

\section{Acknowledgments}

The authors thank the Natural Science and Engineering Research Council of Canada (NSERC), for operating and equipment grants to J. M. Miller, and Tim R. B. Jones for technical assistance.

\section{References}

1. (a) Hanzlik, R. P. Inorganic Aspects of Biological and Organic Chemistry; Academic Press; New York, 1976; pp 29-37; (b)
Cown, J. A. Inorganic Biochemistry, VCH: New York, 1993; Chaps. 3 and 6.

2. (a) Pedersen, C. J. J. Am. Chem. Soc. 1967, 89, 7017-7036; (b) Lehn, J. M. Acc. Chem. Res. 1978, 11, 49-57.; (c) Christensen, J. J.; Eatough, D. J.; Izatt, R. M. Chem. Rev. 1974, 74, 351-384.

3. Shehori, E.; Jagur-Grodzinski, J. J. Am. Chem. Soc. 1972, 94, 7957-7962.

4. Sharma, R. B.; Blades, A. T.; Kebarle, P. I. Am. Chem. Soc. 1984, 106, 510-516.

5. Frensdorff, H. K. J. Am. Chem. Soc. 1971, 93, 600-606.

6. Lehn, J. M. Angew. Chem. Int. Ed. Engl. 1990, 29, 1304-1319.

7. Haymore, B. L.; Lamb, J. D.; Izatt, R. M.; Christensen, J. J. Inorg. Chem. 1982, 21, 1598-1602.

8. Davidson, W. R.; Kebarle, P. J. Am. Chem. Soc. 1976, 98, 6133-6138.

9. (a) Maleknia, S.; Brodbelt, J. J. Am. Chem. Soc. 1992, 114, 4295-4298; (b) Maleknia, S.; Brodbelt, J. Rapid Commun. Mass Spectrom. 1992, 6, 376-381; (c) Liou, C. C.; Brodbelt, J. S.; J. Am. Soc. Mass Spectrom. 1992, 3, 543-548; (d) Liou, C. C.; Brodbelt, J. S. J. Am. Chem. Soc. 1992, 114, 6761-6764; (e) Zhang, H.; Dearden, D. V. J. Am. Chem. Soc. 1992, 114, 2754-2755; (f) Maleknia, S.; Brodbelt, J. J. Am. Chem. Soc. 1993, 115, 2837-2843; (g) Chu, I. H.; Zhang, H.; Dearden, D. V.; J. Am. Chem. Soc. 1993, 115, 5736-5744.

10. Colton, R.; Mitchell, S.; Traeger, J. C. Inorg. Chim. Acta 1995, 231, 87-93.

11. Miller, J. M.; Brown, S. J.; Theberge, R.; Clark, J. H. J. Chem. Soc. Dalton Trans. 1986, 2525-2528.

12. Dey, M.; Moritz, F.; Grotemeyer, J.; Schlag, E. W. J. Am. Chem. Soc. 1994, 116, 9211-9215.

13. Mallis, L. M.; Russell, D. H. Int. J. Mass Spectrom. Ion Processes 1987, 78, 147-178.

14. Bradshaw, J. S.; Krakowiak, K. E.; Izatt, R. M.; Bruening, R. L.; Tarbet, B. J. J. Heterocyclic Chem. 1990, 27, 347-349.

15. Sakai, T. T.; Pogolotti, A. L., Jr.; Santi, D. V. J. Heterocyclic Chem. 1968, 5, 849-851.

16. Leonard, N. J.; Carraway, K. L.; Helgeson, J. P. J. Heterocyclic Chem. 1965, 2, 291-297.

17. Lee, Y. C.; Popov. A. I.; Allison, J. Int. J. Mass Spectrom. Ion Phys. 1983, 51, 267-277.

18. Hobza, P.; Sandorfy, C. J. Am. Chem. Soc. 1987, 109, 1302-1307.

19. Meot-Ner, M. I. Am. Chem. Soc. 1979, 101, 2396-2403.

20. (a) Hardin, E. D.; Fan, T. P.; Blakley, C. R.; Vestal, M. L. Anal. Chem. 1984, 56, 2; (b) Caprioli, R. M. ACS Sym. Ser. 1985, 291, 209; (c) Hilscher, L. W.; Hanson, C. D.; Russell, D. H.; Raushel, F. M. Biochemistry 1985, 24, 5888.

21. Meot-Ner, M. J. Am. Chem. Soc. 1983, 105, 4912-4915.

22. Sigel, H.; Martin, R. B. Chem. Rev. 1982, 82, 385-426.

23. (a) Mallis, L. M.; Russell, D. H. Anal. Chem. 1986, 58, 1076-1080; (b) Teesch, L. M.; Adams, J. J. Am. Chem. Soc. 1991, 113, 812-820; (c) Hu, P.; Gross, M. L. J. Am Soc. Mass Spectrom. 1994, 5, 137-143.

24. Bowen, R. D.; Danks, T. N.; Mitchell, D.; Thomas, S. E. Org. Mass Spectrom. 1988, 23, 674-676.

25. Ulrich, J.; Teoule. R.; Massot, R.; Cornu, A. Org. Mass Spectrom. 1969, 2, 1183-1199.

26. Rice, J. M.; Dudek, G. O. I. Am. Chem. Soc. 1967, 89, 2719-2725. 